Ethos (Jurnal Penelitian dan Pengabdian Masyarakat): 97-104

\title{
Ibm Pengrajin Meja Dan Kursi Di Kelurahan Buladu Kota Gorontalo
}

\author{
TABLE AND CHAIRS CRAFTSMAN IBM In BULADU VILlAGE GORONTALO DisTRICT
}

\author{
Ayuddin \\ Fakultas Teknik, Universitas Negeri Gorontalo \\ E-mail: ayuddin_ung@rocketmail.com
}

\begin{abstract}
The Gorontalo Community still rely on tables and chairs furniture made from rattan, but along with the time, tables and chairs from rattan is already becoming obsolete, one reason is growing furniture design that more convincing than other materials such as wood and aluminum. The society Devotion (IBM) will provide re-design solutions for a table and chairs made from rattan by considering three main concepts, namely efficiency, aesthetic, and functional. With this concept can produce tables and chairs that are more innovative, powerful, and has a higher aesthetic so that it becomes a product of superior competition. Specific targets to be achieved is the increase: 1) knowledge and skills about designing tables and chairs from rattan using three concepts, namely efficiency, aesthetic, and functional, 2) increased revenue artisans from rattan tables and chairs. In addition to these targets, also the administrative improvement craftsmen and marketing management. The method used is the training and assistance directly to the artisans of the strategies and techniques in the manufacture of tables and chairs made of rattan. The results are expected to be an increase in the sale price so that the welfare of artisans tables and chairs to be better in the future.
\end{abstract}

Keywords: fornitur rattan tables and chairs, efficiency, aesthetic, and functional

\begin{abstract}
Abstrak. Masyarakat Gorontalo pada umumnya masih mengandalkan fornitur meja dan kursi yang terbuat dari rotan, Namun seiring dengan perkembangan hasil produk meja dan kursi dari rotan tersebut sudah mulai ditinggalkan, salah satu penyebabnya adalah berkembangnya desain furnitur yang lebih meyakinkan dari bahan yang lain seperti kayu dan alumunium. Pengabdian masyarakat ini (IbM) akan memberikan solusi re-desain untuk meja dan kursi yang terbuat dari rotan dengan memperhatikan tiga konsep utama, yaitu efesiensi, estetis, dan fungsional. Dengan konsep ini dapat menghasilkan produk meja dan kursi yang lebih inovatif, kuat, dan memiliki estetika yang lebih tinggi sehingga menjadi produk yang unggul dalam berkompetisi. Target khusus yang ingin dicapai adalah terjadinya peningkatan: 1) pengetahuan dan keterampilan tentang mendesain meja dan kursi dari rotan dengan menggunakan tiga konsep, yaitu efisiensi, estetis, dan fungsional, 2) peningkatan pendapatan pengrajin meja dan kursi dari rotan. Selain target tersebut, juga terjadinya perbaikan administrasi pengrajin dan manajemen pemasaran. Metode yang digunakan adalah pelatihan maupun pendampingan secara langsung kepada pengrajin tentang strategi dan teknik dalam pembuatan meja dan kursi yang terbuat dari rotan. Hasil yang diharapkan akan terjadinya peningkatan harga jual sehingga kesejahteraan pengrajin meja dan kursi menjadi lebih baik di masa yang akan datang.
\end{abstract}

Kata Kunci: furnitur rotan meja dan kursi, efesiensi, estetis, dan fungsional

\section{Pendahuluan}

Gorontalo merupakan salah satu penghasil rotan di bagian Sulawesi. Hal ini yang menyebabkan animo masyarakat Gorontalo memanfaatkan material rotan sebagai 
sumber pekerjaan dalam bidang forniture. Seiring dengan itu, maka berkembang industri furniture yang memanfaatkan material rotan sebagai bahan lokal. Industri furnatur yang paling banyak dikembangkan adalah forniture meja dan kursi. Akan tetapi, hasil desain/produk yang dihasilkan oleh industri furnitur tidak mampu menarik simpatik masyarakat lokal maupun masyarakat luar daerah. Salah satu penyebabnya adalah persaingan di bidang furniture sangat tinggi, terutama yang memanfaatkan material seperti kayu, alumunium, dan besi.

Selain itu trend desain furniture yang berkembang selama ini masih memiliki bentuk-bentuk konvensional yang ternyata tidak efisien dalam proses produksi, nilai estetika sangat lemah, serta boros dalam pemanfaatan ruang saat proses distribusi maupun penyimpanannya. Permasalahan lain muncul dari karakteristik material rotan itu sendiri. Sifat material yang mudah untuk dilengkungkan dan lentur, membuat struktur ataupun konstruksi furnitur rotan yang dihasilkan perlu menggunakan supportsupport tambahan untuk mempertahankan bentuk hasil bending rotan. Support tambahan pada furnitur rotan biasanya berbentuk struktur silang yang menempel secara permanen pada bagian kaki kursi/meja. Hal ini membuat furnitir- furnitur rotan sulit untuk memiliki sistem bongkar-pasang atau lipat, bahkan untuk proses stacking-pun menjadi tidak seoptimal kursi dari material kayu atau aluminium yang minim supporsupport tambahan.

Oleh karena itu, perlunya dilakukan eksplorasi struktur untuk meningkatkan efisiensi loadibility furnitur rotan melalui inovasi desain pada bentuk struktur furnitur rotan, serta penggunaan kombinasi material yang sesuai. Fokus utama dari eksplorasi struktur dan kombinasi material yang dilakukan ini adalah untuk mendapatkan inovasi yang mampu mengangkat citra dan nilai jual produk furnitur rotan dengan pendekatan desain yang mengacu pada tiga faktor utama, yaitu : efisiensi, estetis dan fungsional. Konsep desain yang dikembangkan dalam eksplorasi ini dibuat dengan mempertimbangkan batasan-batasan desain dan segi karakteristik material rotan itu sendiri. Melalui konsep ini diharakan dapat menghasilkan produk forniture rotan yang laris/banyak diminati oleh masyarakat setempat maupun luar daerah. Dengan demikian, konsep yang ditawarkan ini dapat terobsesi masyarakat gorontalo untuk memberdayakan diri dengan mengembangkan usaha forniture rotan untuk meja dan kursi yang lebih menarik.

Untuk mencapai tujuan tersebut, maka akan dilakukan kerjasama dengan pihak industri furniture rotan meja dan kursi. Untuk mewujudkan kerjasama yang baik, maka pelaksana IbM akan memberikan fasilitas sesuai dengan kebutuhan, rancangan model, strategi pekerjaan dan memberikan pembimbingan secara langsung kepada pihak pengrajin tersebut dengan mengacu pada tiga konsep utama, yaitu efesiensi, estetis, dan fungsional

\section{Metodologi Penelitian}

\section{Flowchart Pelaksanaan}

Pelaksanaan kegiatan dilakukan melalui beberapa tahapan, seperti ditunjukkan pada Gambar 1. 


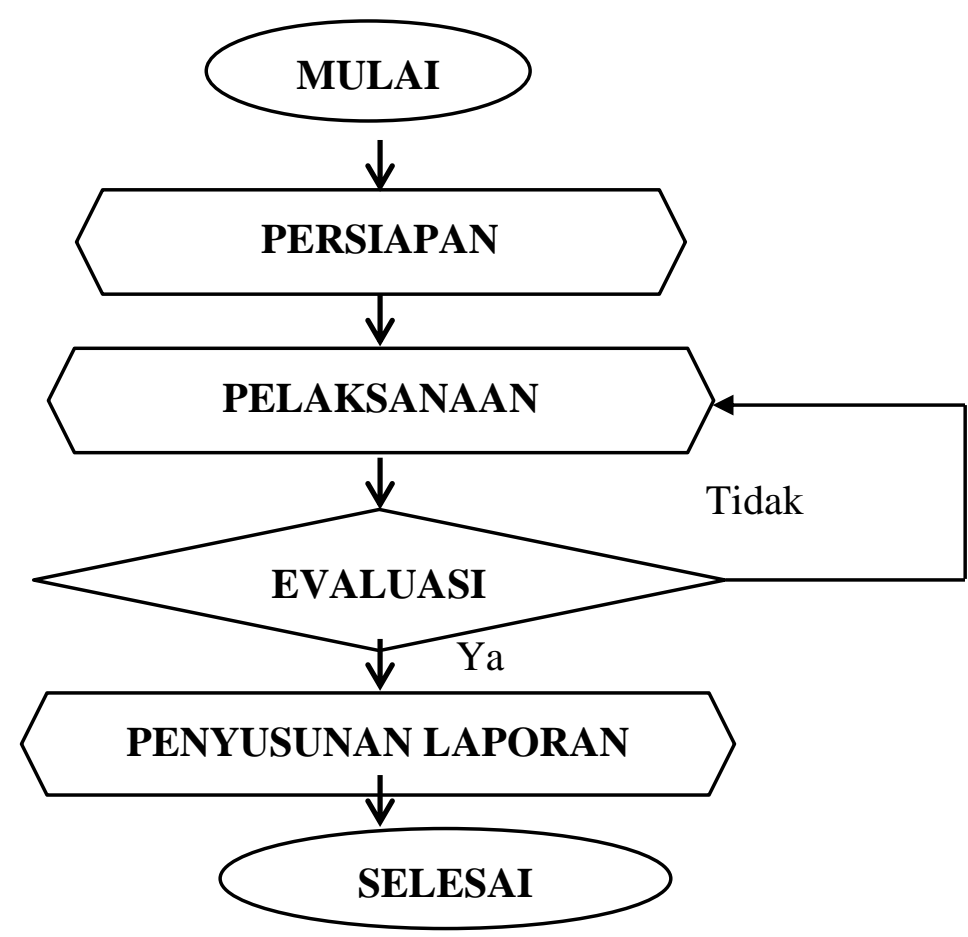

Gambar 01. Diagram Alir Pelaksanaan

Kegiatan pengabdian kepada masyarakat ini melalui beberapa tahapan, meliputi :

\section{Tahap Persiapan}

- Survei tempat pelaksanaan kegiatan ipteks IbM, dalam hal ini adalah kelurahan Buladu dan Libuo kecamatan kota barat kota Gorontalo.

- Wawancara dilakukan kelompok pengrajin rotan kursi dan meja dengan tujuan untuk keperluan pelatihan yang akan dilakukan dan mengarahkan mengikuti model yang sudah didesain.

- Pembuatan materi pelatihan

Materi pelatihan ini berkaitan dengan model yang akan diikuti dan pengembangan model-model lainnya. Materi ini juga diajarkan cara melengkung rotan, menganyam rotan, dan memperhitungkan aspek kekuatannya.

\section{Pelaksanaan kegiatan}

Rencana pelaksanaan kegiatan dibagi menjadi beberapa tahap, yang akan dibahas pada hasil dan pembahasan.

\section{Evaluasi}

Tahapan ini dilakukan untuk mengetahui tingkat keberhasilan kegiatan, sehingga dapat dilakukan penyempurnaan apabila terdapat kekuarangan didalamnya.

\section{Rancangan Evaluasi.}

Evaluasi ini bertujuan untuk mengetahui apakah terdapat peningkatan kerja baik dari segi metode maupun pengembangan kreativitas pengrajin dengan memperhitungkan tiga konsep utama, yaitu: efesiensi, estetis, dan fungsional.

Penyusunan laporan kemajuan dan laporan akhir dari kegiatan pengabdian Ipteks IbM yang dilaksanakan. 


\section{Hasil dan Pembahasan}

\section{Target Luaran}

Berdasarkan rumusan masalah yang telah dipaparkan dalam proposal pengabdian kepada masyarakat IbM, maka target luaran yang diharapkan adalah :

[1]. Pihak pengrajin rotan meja dan kursi dapat memahami teknik desain yang beriorentasi pada efesiensi, estetis, dan fungsional.

[2]. Pihak pengrajin rotan meja dan kursi dapat mengembangan kreasi fornitur rotan dengan kebutuhan pasar sesuai tuntutan modernisasi.

[3]. Pihak pengrajin rotan meja dan kursi dapat memahami teknik pemasaran fornitur rotan.

[4]. Pihak pengrajin meja dan kursi dapat memahami cara membuat fornitur rotan dengan berbagai kebutuhan buyer.

\section{Metode Pelaksanaan}

Metode yang digunakan ini dalam menyelesaikan masalah melalui program IbM ini adalah metode pelatihan secara langsung (training), demonstrasi percobaan, dan pembinaan pengembangan usaha terhadap pengrajin rotan.

\section{Metode Pelatihan}

Tujuan dari metode pelatihan ini adalah :

[1]. Untuk menanamkan kecakapan, ketrampilan teknis, dan praktis dalam membuat fornitur rotan meja dan kursi yang memiliki nilai artistik yang tinggi,

[2]. Memberikan gambaran konkrit di tempat kerja tentang teknik pembuatan fornitur rotan meja dan kursi dengan berbagai variasinya.

[3]. Untuk menghasilkan fornitur rotan meja dan kursi yang dapat bersaing dengan fornitur bahan lainnya.

[4]. Mencipatkan lapangan kerja yang berkelanjutan, dan

[5]. Dapat meningkatkan pendapatan usaha pengrajin rotan meja dan kursi.

\section{Demonstrasi Percobaan}

Kegiatan percobaan atau demonstrasi dilakukan setelah dilaksanakan pelatihan teknik pembuatan meja dan kursi dari rotan. Pengrajin rotan ini dibimbing dan dibina yang berkenaan dengan materi pelatihan. Selanjutnya dilakukan demonstrasi percobaan yang mencakup: Cara pembuatan rangka yang memperhatikan nilai artistik, kekuatan rangka, dan penempatan rotan secara fungsional. Di samping itu, dalam meningkatkan pendapatan, kelompok pengrajin rotan sebagai usaha mitra juga diberi keterampilan mengenai strategi memodifikasi desain yang memperhatikan efisiensi, estetis, dan fungsional. 
Tabel 1. Ketercapaian Target Luaran

\begin{tabular}{|c|l|c|l|}
\hline No & \multicolumn{1}{|c|}{ Target } & Prosentase & \multicolumn{1}{|c|}{ Keterangan } \\
\hline 1 & $\begin{array}{l}\text { Pengrajin rotan kursi dan meja } \\
\text { dapat memahami konsep teknik } \\
\text { desain yang beriorentasi pada } \\
\text { efesiensi, estetis, dan fungsional }\end{array}$ & $80 \%$ & $\begin{array}{l}\text { Sudah dilakukan } \\
\text { pelatihan atau } \\
\text { bimbingan } \\
\text { langsung }\end{array}$ \\
\hline 2 & $\begin{array}{l}\text { Pengrajin rotan kursi dan meja } \\
\text { dapat memahami rancangan atau } \\
\text { model desain yang diberikan. }\end{array}$ & $\begin{array}{l}\text { Sudah dilakukan } \\
\text { pelatihan atau } \\
\text { bimbingan } \\
\text { langsung }\end{array}$ \\
\hline
\end{tabular}

\section{Permasalahan dan Penyelesaian}

\section{[1]. Permasalahan Teknis}

Adapun permasalahan yang ditemukan selama pelaksanaan pelatihan pembuatan kursi dan meja dari rotan adalah sebagai berikut:

Para pengrajin rotan masih mengingat konsep desain lama dan belum sepenuhnya memahami teknik desain yang beriorentasi pada efesiensi, estetis, dan fungsional. Permasalahan teknis lainnya, masih sering mendapatkan kendala saat pekerjaan berlangsung dalam pemahaman rancangan atau model desain yang diberikan.

\section{[2]. Penyelesaian Teknis}

Permasalahan teknis terhadap masalah yang ditemukan di lapangan diantisipasi dengan pemberian bimbingan langsung saat pekerjaan pembuatan kursi dan meja terutama pada tiga konsep yang harus diikuti, yaitu efesiensi, estetis, dan fungsional. Begitu juga model yang sudah diberikan sebagai job kerja harus diikuti untuk memanimalisir kesalahan yang mungkin terjadi. Pelatihan atau bimbingan langsung yang diberikan kepada pengrajin rotan kursi dan meja memberikan hasil yang sangat memuaskan baik isi materi yang diberikan maupun tanggapan pengrajin rotan terhadap instruktur juga sangat baik. Tanggapan pengrajin rotan dapat dilihat pada gambar 02 dan gambar 03.

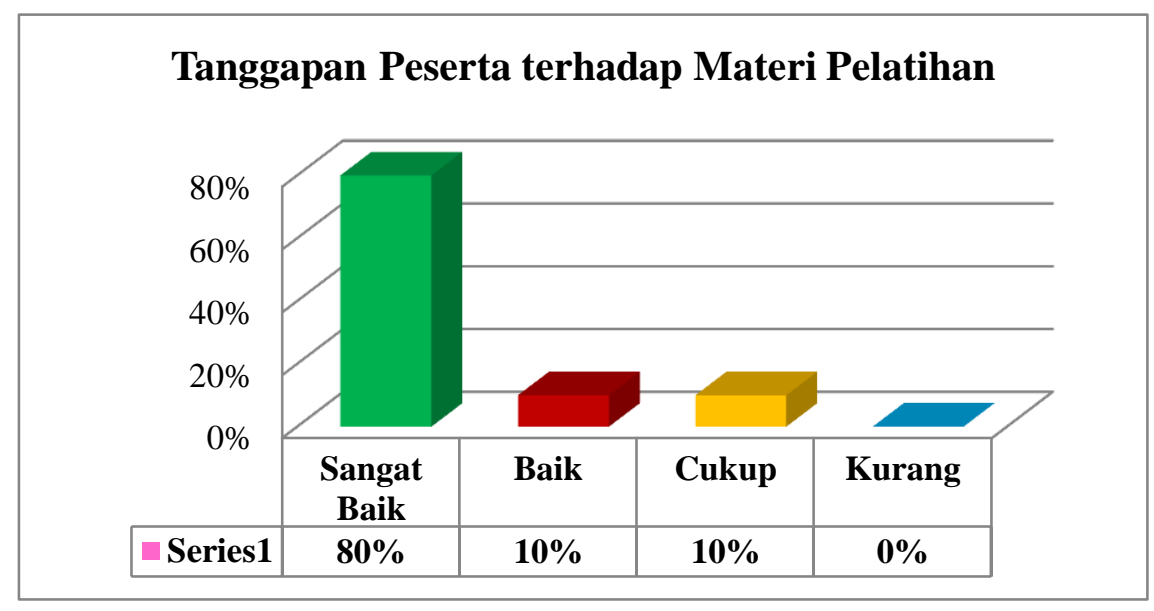

Gambar 02. Tanggapan Pengrajin terhadap Materi 
102 | Ayuddin

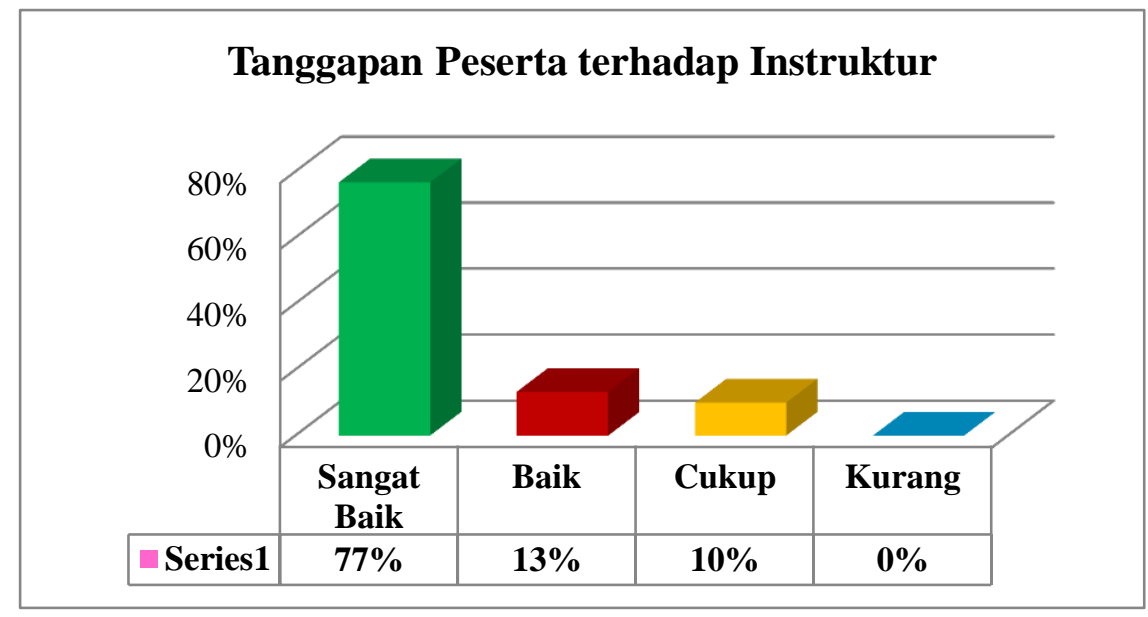

Gambar 03. Tanggapan Peserta terhadap Instruktu

\section{Dokumentasi :}
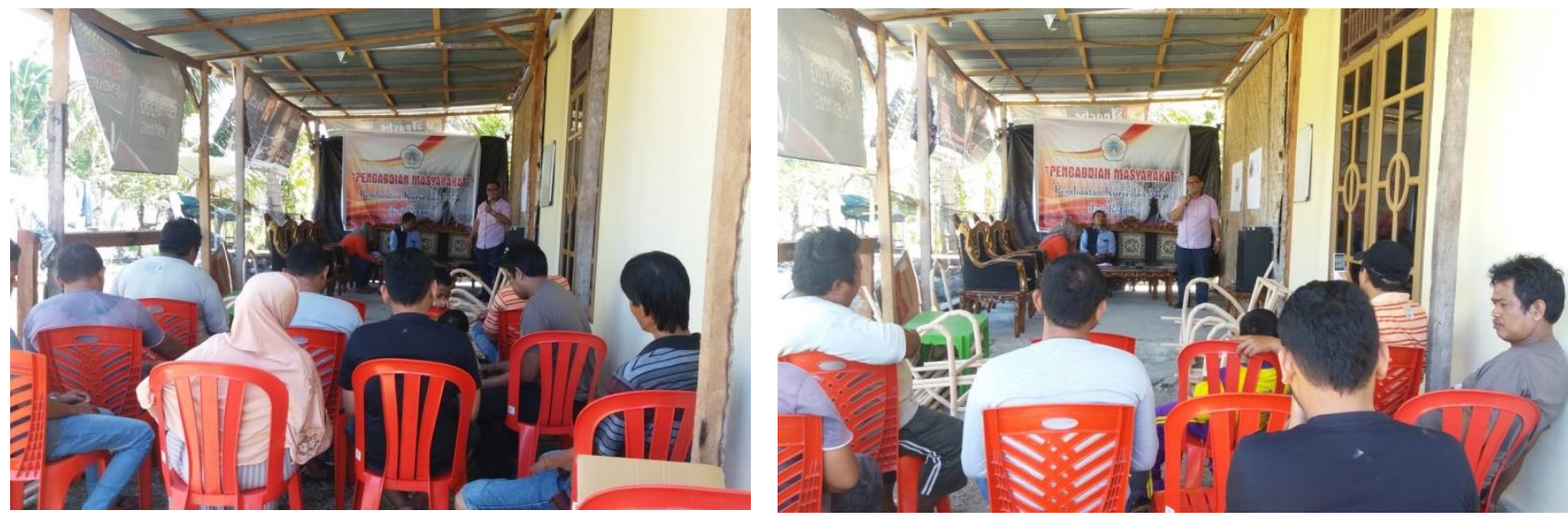

Gambar 04. Kegiatan Pembukaan Pelatihan
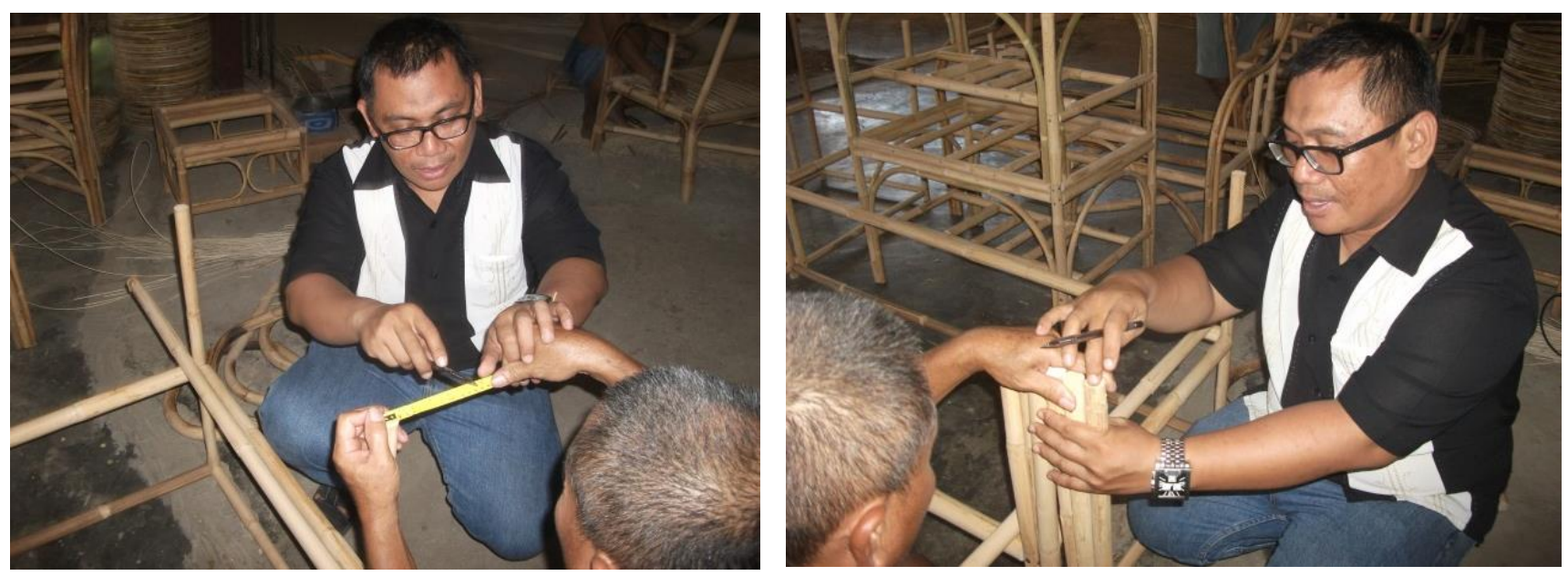

Gambar 05. Pelatihan teknik keseimbangan rangka 

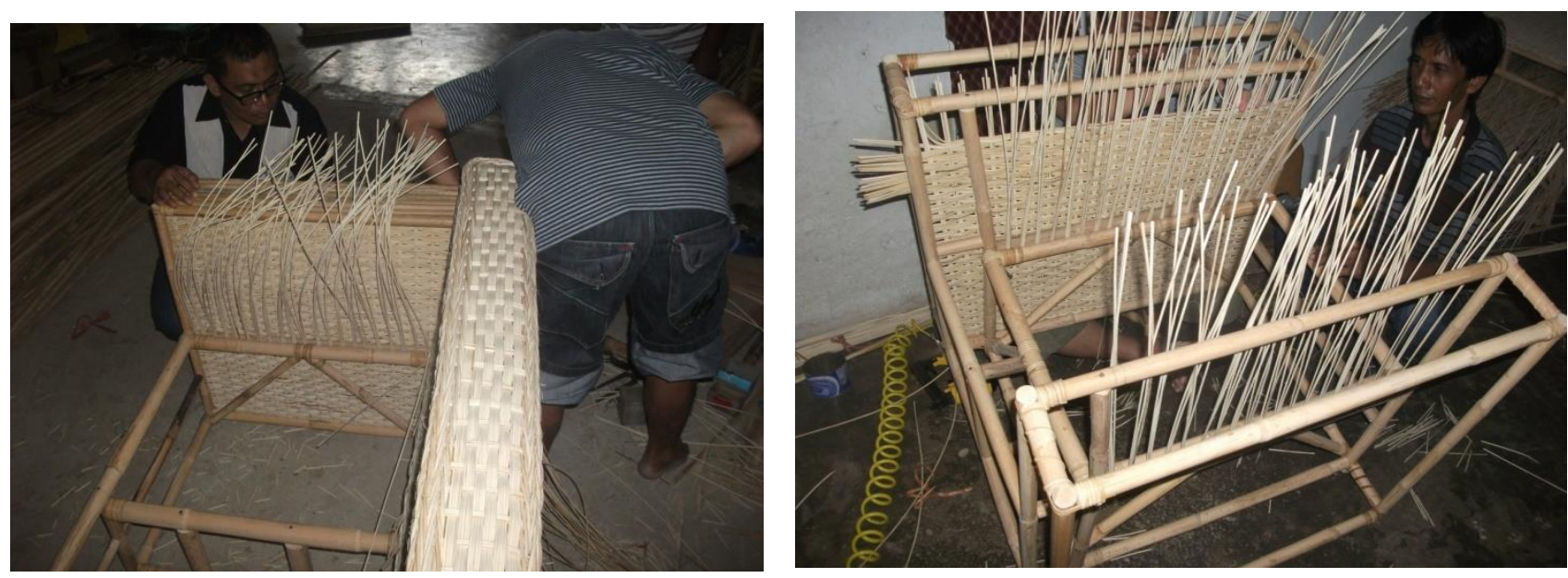

Gambar 06. Pelatihan Pembuatan rangka
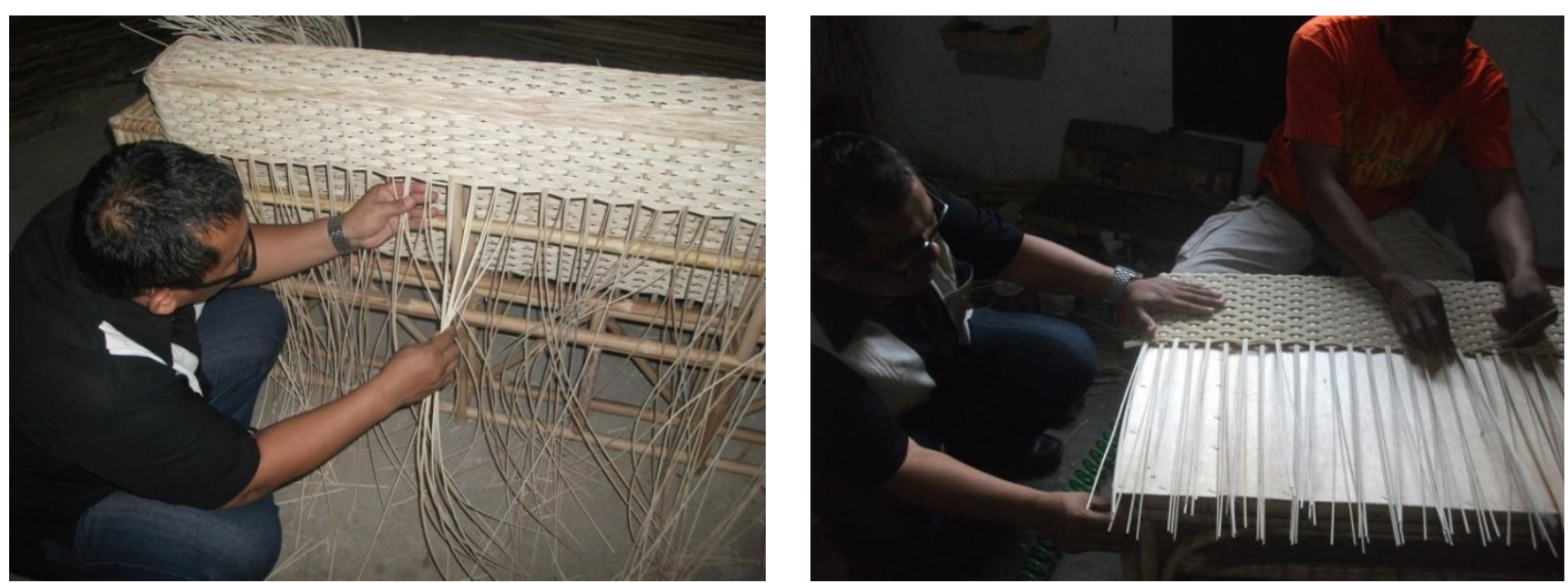

Gambar 07. Pelatihan menganyam rotan

\section{Kesimpulan}

Dari uraian pembahasan kegiatan pengabdian IbM yang telah dilakukan ini dapat diperoleh beberapa kesimpulan sebagai berikut :Pengrajin rotan kursi dan meja dapat memahami konsep efesiensi, estetis, dan fungsional setelah diberikan pelatihan maupun bimbingan langsung. Tingkat pemahamannya dapat mencapai $80 \%$ dari isi materi yang diberikan. Pengrajin rotan kursi dan meja masih terbiasa dengan konsep lama sehingga konsep desain baru yang diberikan sebagai bahan pelatihan kelihatan sangat kaku dalam mengerjakannya. Pemikiran pengrajin rotan kursi dan meja tentang kompetisi terhadap pengrajin lainnya yang memanfaatkan bahan seperti kayu, alumunium, dan besi masih sangat lemah. Kegiatan pelatihan maupun bimbingan langsung kepada pengrajin rotan kursi dan meja sangat bermanfaat dan sangat dibutuhkan terkait dengan konsep, metode maupun cara pelaksanaannya.

\section{Ucapan Terima Kasih}


104 Ayuddin

\section{Daftar pustaka}

Anonim, 2003. Peningkatan Desain Produk Mebel dengan Pendekatan Ergonomik. Laporan Penelitian kerjasama antara PT. Gama Multi Usaha Mandiri dengan Deperindag. Jakarta.

Bappenas, Direktorat Pengembangan Kawasan Khusus dan Tertinggal, Panduan Pembangunan Klaster Industri: Untuk Pengembangan Ekonomi Daerah Berdaya Saing Tinggi, (Jakarta: 2004) Http://Kawasan.Or.Id

Departemen Perindustrian dan Perdagangan. 2002. Rencana Induk Pengembangan Industri Kecil Menengah. Departement Perindustrian dan Perdagangan Republik Indonesia.

Januminro CFM. 2000. Rotan Indonesia. Yogyakarta: Kanisius.

Ulrich, K.T. 1995. Product Design and Development 2 cd Ed. Mc. Grow-Hill Book Co. Singaporemeubel 